Winter 10-1-2003

\title{
Painting, Photography and Fidelity in The Tragic Muse
}

Adam Sonstegard

Cleveland State University, a.sonstegard@csuohio.edu

Follow this and additional works at: https://engagedscholarship.csuohio.edu/cleng_facpub

Part of the Literature in English, North America Commons

How does access to this work benefit you? Let us know!

Publisher's Statement

Copyright (C) 2005 The Johns Hopkins University Press. This article first appeared in Henry James Review, Volume 24, Issue 1, Winter 2003, 27-44.

\section{Recommended Citation}

Sonstegard, Adam, "Painting, Photography and Fidelity in The Tragic Muse" (2003). English Faculty Publications. 27.

https://engagedscholarship.csuohio.edu/cleng_facpub/27

This Article is brought to you for free and open access by the English Department at EngagedScholarship@CSU. It has been accepted for inclusion in English Faculty Publications by an authorized administrator of EngagedScholarship@CSU. For more information, please contact library.es@csuohio.edu. 


\title{
Painting, Photography, and Fidelity in The Tragic Muse
}

\author{
By Adam Sonstegard, \\ Washington University
}

Let me at any rate have some sort of sketch of you as a kind of feather from the angel's wing or a photograph of the ghost-to prove to me in the future that you were a solid sociable fact, that I didn't invent you, didn't launch you as a deadly hoax.

-Nick Dormer to Gabriel Nash, Henry James, The Tragic Muse

Like Henry James's character Nick Dormer in my epigraph from The Tragic Muse (1890), this essay brings together James's attitudes toward painting and photography. Nick, a bureaucrat and aspiring portraitist, likens his own craft to photography. He wishes to paint his elusive friend Gabriel Nash, but he regards the portrait as a kind of occult "photograph," a document that could prove the presence of a ghost. Critical histories of James and photography tend to elide Nick and the many other artists and artworks of The Tragic Muse, concentrating instead on The Golden Bowl and James's relationship with Alvin Langdon Coburn. ${ }^{1}$ But the novel clearly indicates that for James, some photographs approach the elegance of Nick's artful portrait, while other paintings approach the rampant replication and distortion of less desirable photographs. The difference lies in a representation's truth to an original image and in the artist's personal integrity in representing that image. A portrait's success, that is, rests with both the artwork's and the artist's fidelity.

Indeed, in many of James's narratives, he tests the degree of fidelity that artists in varied media can have to their ideals or to their families as well as to their artistic pursuits. Reflecting James's own interest in writing for the stage, The Tragic Muse weighs the novelistic against the theatrical art. James writes a sprawling story of artists who in turn measure their own art against other media, their own conduct against that of other artists. Many readers devote their 
attention to a single character, studying Nick Dormer as an upper-class Englishman, Miriam Rooth as a Jew, or Gabriel Nash as a homosexual, and thereby limit their observations to James and classism, James and anti-Semitism, ${ }^{2}$ or James and homoeroticism. ${ }^{3}$ But in more inclusive terms this novel scrutinizes various races and gender roles to observe the extent to which society allows each artist to balance representational freedom with tribal or familial allegiance. To some degree, artists can recreate themselves freely via their chosen artistic medium and assume a performed identity. But to some degree as well, the artist's family history and artistic medium predetermine the identities he or she can perform. Dramatizing each character's "choice" between fidelity to a family or fidelity in artistic representations, James resists the assumption that all families, all races, and all understandings of gender allow individuals the same options. Fidelity in art comes into conflict with fidelity in life, impinges upon the artist's sense of identity, and varies from person to person, medium to medium, and family to family. Much to his fiancée's chagrin, Nick Dormer shows too little fidelity as he paints a portrait of the actress Miriam Rooth. Much to his own chagrin, his portrait of Gabriel Nash shows too much fidelity to the sitter's character, when, like a true "photograph of the ghost," it mysteriously fades from the canvas. These issues resonate so strongly for James that he revisits Nick's conflicted career later in his own artistic life. He pauses in A Small Boy and Others (1913) to highlight his family fidelity and reproduce his own "photograph of the ghost."

\section{"The poetry of fidelity"}

As early as 1865 , James would write in the North American Review that Balzac's wealth of detail comes across with the "fidelity of the photograph" (CM 26). James is probably among the first to extend the denotation of "fidelity" metaphorically, from an individual's integrity and conjugal loyalty, to a photograph's resemblance to an original image. ${ }^{4}$ Even in Roderick Hudson (1875), the novel that would inaugurate his definitive New York Edition, fidelity becomes a vexed concern. When Roderick renders his mother's countenance in a sculptural bust, the narrator explains, "Roderick had produced its sweetness, its mildness, its minuteness, its maternal passion, with the most unerring art. The thing was perfectly unflattered and yet admirably tender; it was the poetry of fidelity" (281). Here Roderick's "unerring art" allows him to be an artist with an exacting eye and a son with a strong family devotion. Artistic verisimilitude can harmonize with personal integrity and familial loyalty. When Roderick completes a bust of Christina Light, however, the narrator remarks, "The resemblance was deep and vivid; there was extreme fidelity of detail, and yet a noble simplicity" (RH 165). Here he may adroitly incorporate details into a graceful whole, but he has greater trouble with opposing loyalties. He shows "fidelity of detail," such as minute accuracy in his carving and etching. But he shows infidelity "in the details." Gazing upon Christina Light as he sculpts that bust, he flirts in Europe while his fiancée, Mary Garland, remains in America. James considers both the fidelity promised by an artistic medium and the potential infidelity of an individual who works with that medium and takes personal and artistic liberties. 
For Nick Dormer in The Tragic Muse, painting is liberty while his career as a politician is duty and obligation. In the novel's opening pages, he decides between representing a borough of the British countryside in the House of Commons or representing subjects of his choice on canvas. His widowed mother, Lady Agnes, worries over finances and prefers that Nick draw a politician's income to support the family. Neither Nick nor his two younger sisters, Biddy and Grace, have any immediate prospects for successful marriages, and, as Lady Agnes becomes increasingly frustrated, she pressures Nick's vocational and marital choices. James avails himself of an array of puns to reveal many of Nick's "choices" to be covert obligations. Julia Dallow, as the chief political benefactor for the oddly-named borough, wishes Nick to be her husband and to "stand for Harsh." Julia will "go straight down to Harsh" if she does not get her way (TM 42). But even with her influence, Nick would rather "stand for art" as a portraitist. Indeed, he does not wish to stand for his constituents at all, but to have them "sit to him" as he paints. He must "represent," one way or the other. Julia and his family pressure him to represent politically, while his own fancy and sense of uniqueness encourage him to represent artistically.

Three other would-be artists have an easier time coping with this supposed choice between representing family interests and representing chosen subjects in art. Even Nick's youngest sister, diminutively named Biddy, practices her art with a wider range of freedom than he can enjoy. James's only woman sculptor in a major novel, Biddy shares Nick's art studio as a haven from the rest of the family and openly questions the idea that artists necessarily play marginal roles in national affairs. Miriam Rooth, rising from aspiring dramatist to accomplished actress, also gains an artistic license that contrasts with Nick's array of obligations. While her acting coaches, doting mother, and doubtful critics debate her ability to act British and French roles, Miriam disregards these nationalist concerns and develops a flexible, polyglot genius. She draws on her mixed but vaguely Jewish ancestry to increase her exotic air. Her existence as a kind of chameleon of the stage, to which I will return, grants her almost the same degree of freedom enjoyed by the mysterious Gabriel Nash. A footloose aesthete with full economic independence, Gabriel does not even feel obligated to produce any art. Author of a vaguely experimental novel and variously identified by critics as Oscar Wilde or Herbert Pratt, ${ }^{5}$ Gabriel only seems to exist in the narrative in order to be coyly mysterious and to try to rearrange the other characters' aspirations. When he is asked to explain why he never struggles with his art, Gabriel confidently asserts, "I work in life" (TM 105). James suggests that a character's chosen genre for art insidiously corresponds with his or her assigned place as a son or daughter, heir or heiress. Families grant some members a wide range of choices, while making exacting demands of others. Nick's English family background determines his mode of representation; Miriam finds she can alter her ethnic heritage to suit her present needs; and Gabriel never seems to have a background in the first place.

Julia Dallow and Peter Sherringham meanwhile embody citizenship and duty, representing politics instead of art. Julia, the wealthy and still marriageable widow of one of Harsh's political bosses, holds few governmental theories of her 
own except an utter hatred for Tories. She wishes to be the wife of Harsh's representative in the House of Commons more than she wishes to devote herself to Nick. He is merely a likely candidate for government as well as for matrimony. Her brother Peter Sherringham works as a minor diplomat, but spends most of his time courting both Biddy Dormer and Miriam Rooth. He makes irrational demands of Miriam (instead of proposing to her as a gentleman), eventually becomes an ambassador to a republic in Central America, and generally fails to win readers' sympathies. The novel's love relationships show a complex symmetry: Peter courts Nick's sister Biddy (when he is not pursuing Miriam). Nick makes similar proposals to Peter's sister Julia (when he is not painting). If either man succeeds, he will make the other his brother-in-law. Peter pursues a talented actress (Miriam), but wants to change her into a politician's wife (like his sister, Julia). Nick is engaged to just such a political wife (Julia), but wants someone, perhaps a fellow artist, who understands his aspirations (like his sister, Biddy). In each potential marriage, one partner represents others politically, and the other partner represents himself or herself artistically. Nick and Miriam represent the freedom to pursue artistic fancies. Julia and Peter embody the societal duties they forsake for their art.

Over the course of the novel's action, then, Nick and Miriam struggle with developing their identities as artists and reconciling these identities with their familial or national ties. Nick does become the member for Harsh. With little faith in the political process, Nick makes powerful speeches but finds the process tawdry, his own motives vulgar and cheap. He spends more time listening to Gabriel's art criticism than hearing his constituents' concerns. Nick's choice of art over politics becomes a problem for his family as well as for his borough. In a way, Nick's deceased father lives on in Nick's person, and Nick seems to assume this inherited identity as the man of the family and as the local legislator. In the absence of Nick's father, the elderly Mr. Carteret decides whether Nick will receive the Dormer inheritance. Carteret makes it clear that he wishes for Nick to commit himself to Julia and to Harsh. He acts as if Nick should love Julia solely because such an attachment would be logically consistent and politically expedient. Nick is merely acting irrationally, to Carteret's understanding, when he does not promptly fall in love with Julia and father a new generation of Dormers for Harsh. Next to his practical career and rational love for Julia, his flair for painting seems to be the impulsive wooing of a wild muse. Can he swoon for his art without neglecting his sensible, political fiancée? Can he represent freely on canvas and still represent his stodgy borough in the government? The novel repeatedly finds that he cannot be true to Harsh, his fiancée, and his family if he stays true to his muse.

If Nick's background does too much to shape his present identity, Miriam's allows her a wide range of inventive choices. She shows such a facility in acting roles from Shakespeare to Molière that people ask after her "true" nationality. In between rehearsals, Miriam discusses her ethnic background with Peter, who breaks out at one point, "You're a Jewess-I'm sure of that." James narrates:

She jumped at this, as he was destined to see later she would ever jump at anything that might make her more interesting or striking; even at 
things that grotesquely contradicted and excluded each other. "That's always possible if one's clever. I'm very willing, because I want to be the English Rachel." (TM 135)

She will own the Semitic background if it adds dimension to her character, claiming a desire, but not a birthright, to be "the English Rachel." Eli Ben-Joseph sees that Miriam is blithely unaware that these two heritages are "grotesquely," mutually exclusive (108). But as others have pointed out, the term admits of further ambiguity: Miriam could be referring of course to the biblical heroine Rachel. But she could also mean Elisa Felix (1820-1858), an actress of mixed Jewish ancestry who became famous for portraying this character. Leaving her reference ambiguous, Miriam quickly outlines both Jewish lineage and exogamy in her family past. Never settling the matter precisely, she inspires Peter to conclude: "Put all that together and it makes you very sufficiently of Rachel's tribe." She responds, "I don't care if I'm of her tribe artistically. I'm of the family of the artists-je me fiche of any other! I'm in the same style as that woman-I know it" (135). Miriam affiliates herself with a loosely organized clan of artists. Her reference to "that woman" seems to mean Felix, who had chosen a similar theatrical affiliation. With "je me fiche-itself an adopted expression of foreignness-she rejects inheritance and nationality and embraces occupation and performance as proper indicators of identity. Peter seeks her "real" family origin, asking which relations in family history determine her individual ethnic identity. But Miriam elects to join a particular tribe, paying scant attention to her ancestors" "choices" in this regard.

Miriam's freedom of affiliation seems paradoxically to depend upon her national heritage. If she is Jewish, she gains a mysterious allure that elevates her above identifiably Anglo actresses. But if she might be Jewish, the mystery deepens all the more. A character who invoked an English or Irish heritage in this manner would sound coy or even absurd. But a Jewish background allows Miriam to exploit her own potential for exoticism. John Carlos Rowe demonstrates that in concocting an identity, she combines her background with her observers' uninformed perceptions: “The 'Jewishness' that various characters seek to confirm in her appearance, her ancestry, her career, and her social behavior is far more the consequence of Victorian anti-Semitism than anything intrinsic to [her] character or ancestry" (77). Without demanding loyalty to her tribe's traditions, Miriam's Jewishness capitalizes upon the qualities that outsiders attribute to that tribe. Nick, who has to renounce one form of representation for another, who neglects his obligations as a son of the Dormer family and a member for Harsh each time he takes up a painter's brush, comes to envy both the actress's facility and the Semite's flexibility.

Toward its conclusion, however, the novel partially discounts Miriam's theory of adopted lineage. Nick is speaking with Miriam's mother in his studio when he inadvertently notes that her posture and carriage "gave such a splendid pictorial glimpse of the element of race" (414). This conveniently classificatory "glimpse" leads him to a profound reverie: 
He found himself seeing the immemorial Jewess in her hold up a candle in a crammed back shop. There was no candle indeed and his studio was not crammed, and it had never occurred to him before that she was a grand-daughter of Israel save on the general theory, so stoutly held by several clever people, that few of us are not under suspicion. The late Rudolf Roth had at least been, and his daughter was visibly her father's child; so that, flanked by such a pair, good Semitic presumptions sufficiently crowned the mother. (414)

Rudolf Roth is Mrs. Rooth's deceased husband, Miriam's father. Though the father is absent from the novel's action, Nick's speculative survey of the mother, who is gentile by birth, places Miriam within the Jewish "tribe." Nick pictures the absent father and thereby "crowns" the mother, who is present before him, with unambiguous markers of a Semitic heritage. Nick attributes their similarity to their biological inheritance and to the theory that "few of us are not," in one way or another, grandchildren of Israel. The novel is asking when family inheritance shapes an individual's identity and when observers or performers shape an identity for themselves. Such a question touches upon what Ross Posnock calls "Jamesian theatricality," which still operates within limits. It

does not liquidate identity for illegible, unrestrained free play. Instead, its energy derives from manipulating the interplay of both moments of mimesis: its empathic, spontaneous improvisations and its rationalized, strategic defenses and masks. In short, theatricality embodies an immanent critique of the identical and purposive self without being able to overcome that self. (Posnock 185)

Indeed, the enacted "self" takes the inherited "self" as its point of departure. Miriam's inherited "self" carries the surname Roth, but her mother has changed that name to Rooth. The change allows Miriam to add the biblical Ruth to her allusions to Rachel, and to gesture as well toward "ruth," or the kind of empathic pity Posnock sees in her improvisations. Her concocted identity, contingent upon her ethnicity and heritage, affords her performances an impressive latitude. Fascinated by Miriam's way of making herself the person she wants to be, James is nevertheless aware of the heritage that-many of his contemporaries would say-makes her the person she is.

Miriam's fluidity has understandably generated much debate, but a crucial passage remains under-read in the criticism. The way the novel is constructed, Peter and Nick repeatedly experience events that reverberate ironically for the other character. When Peter has this discussion with Miriam about ethnic heritages invoked at will, the scene corresponds to an earlier one in which Nick comes to a reciprocal understanding of his own lineage. Speaking of the Dormer family and its absolute dearth of artists, Nick explains to Gabriel,

there never has been anything of the sort among us; we're all Philistines to the core, with about as much aesthetic sense as that hat. It's excellent 
soil-I don't complain of it-but not a soil to grow that flower. From where the devil then has the seed been dropped? [...] I scour our annals without finding the least little sketching grandmother, any sign of a building or versifying or collecting or even tulip-raising ancestor. (122)

Though Nick does speak ironically, he does not quarrel with genealogical minutiae but laments that his family heritage shows no signs of artistic flair. Our modern understanding of genetics and individual temperament may render the idea ridiculous, but the lack of a "sketching grandmother" in the Dormer line curtails Nick's own artistic ambitions. Without an aesthetically inclined ancestor, Nick cannot hope to develop his own aesthetics. His dependence on his inherited traits readily contrasts with Miriam's nimble invocation of a suitably exotic background. Nick cannot be a qualified English artist unless he is grand-mothered in by an artistic forebear. To Miriam, by contrast, it's never too late to be Jewish.

The question for Nick and for Miriam, then, becomes whether their families allow for fidelity in art. Miriam's initial gift as an actress allows her to "reproduce with a crude fidelity, but in extraordinary detail, the intonations, the personal quavers and cadences of her model" (128). James's preface to the novel indicates that he never gives readers unmediated access to Miriam's mind but allows others to perceive her without discerning her "true" character. ${ }^{6}$ Even when Miriam is acting at "not acting," the other characters are uncertain if they are sharing a true experience with her or merely observing a second-hand representation. Whether she performs before a full house or meets with Peter alone to reject his proposal of marriage, for Miriam, "the show must go on." She seems forever to be performing a role, overacting it and directing it toward the least discerning members of her audience until she seems to belong in vulgar and tawdry theatrical settings. She loses the other characters' faith that she will ever pause in her performances for their sake and tell them the "truth." Some readers have suggested that James attributes her vulgarity specifically to her gender or her ethnicity (Ben-Joseph; Wilson). But once again the novel is asking which individuals of which backgrounds and which gender achieve a freedom of representation without debasing their artistic products or showing disloyalty to their family heritages. Gabriel foresees a time when Miriam

would be at the fine climax of life and glory, still young and insatiate, but already coarse, hard and raddled, with nothing left to do and nothing left to do it with, the remaining years all before her and the raison d'être all behind. It would be splendid dreadful grotesque. (352)

If observers seek the definitive quality in a set of contradictory attributes, Gabriel claims, "You never find the artist-you only find his work, and that's all you need to find" (354). The representation is sufficient, Gabriel proposes, even if it replaces the unalloyed original and obscures the artist's intentions. The other characters recognize fidelity in her representations, but seldom know what relationship her performances bear to "truth." With fidelity to original subjects at stake, Miriam can only claim, "I represent, but I represent truly" (421). 


\section{"Virtual infidelity"}

These issues reach a crisis when Nick undertakes to paint Miriam as the tragic muse. Nick, who cannot stop representing, paints Miriam, who represents so freely she blurs her "true" self. Two individuals who are committed to different ways of representing, and who indeed have different ways of reconciling their performances with their individual identities, come together to make one additional representation. The novel's critics apply almost as much attention to the scene as Nick does paint to his canvas. John Landau, for one, determines that the "real" Miriam emerges from the representations: in Nick's studio "she is no longer an actor or an artist but the subject for Nick's art" (52). Crucially, however, Nick is not painting Miriam as Miriam. He paints her as the tragic muse, an actress playing her part. Readers cannot conclude that his picture captures the "real" Miriam, but represents (in oils) what is already a representation (an enacted role). If art had previously been a conduit to a sincere "truth" beyond the deceptive imitations, here it seems to be part of an endless cycle. As Nick loses what Walter Benjamin calls Miriam's aura, Nick's painting begins to function like a roll of photographic film that duplicates existing images. These two creators of representations make a second-generation copy, a representation of a representation, twice removed from an original.

The narrative certainly suggests that this act of reproduction is impure and, in more than one sense of the word, adulterated. At one point, while he paints Miriam and makes polite conversation, Nick is too preoccupied to reply to Miriam's persiflage. He is "troubled about his sitter's nose, which was somehow Jewish without the convex arch" (266). The process of rendering her, which is otherwise smooth, stalls when he reproduces the feature that supposedly marks her ethnicity. When he is most aware of shaping her image, he has the greatest trouble believing his own myth that as an artist he paints her "just as she is." Miriam poses while partially undressed, and the scene's language is strikingly sexualized: Nick is "pleased with her ejaculation" of approval at his performance, and feels that he "had had a long, happy spurt" when they conclude for the day (269). Julia walks in on them "reproducing," behaves as if she has witnessed adultery, and breaks off her engagement with Nick. Too much attention to the facial features that supposedly mark Miriam's ethnicity means too little attention to his Anglo-Saxon fiancée. To Julia, Nick's artistic representation is a fiancé's transgression.

Some of Nick's friends are inclined to see it in the same light. Gabriel, for one, is certainly willing to see both amatory and aesthetic motives. He explains to Nick with regard to the portrait of Miriam, "While you were engaged in transferring her image to the tablet of your genius you stamped your own on that of her heart" (349). Rendering cannot be disinterested, it seems, but implicates the body's desires in the mind's pursuit of the ideal. The novel would at first have readers believe that Nick pursues a Platonic ideal in his transcendent art and that Julia always has Harsh's best interests in mind. But then the story reduces their motives to mere flirtation and jealousy: perhaps Nick only pursues fidelity in his art to conceal infidelity in life, and perhaps Julia only appears committed to what we might call the politics of Harsh to gain a marital commitment from Nick. Nick 
even wonders to himself in the aftermath, "had he given Julia tangible grounds and was his unexpectedly fine rendering of Miriam an act of virtual infidelity?" (322).

The novel seems to answer such questions in the affirmative, with the worst possible effect on Nick's fortunes. When he has to explain to Mr. Carteret that Julia has broken off their engagement and that he has renounced his seat in the House of Commons to become a portraitist, Carteret disinherits him on behalf of the whole Dormer family. Carteret stammers disapprovingly, "The pencil-the brush? They are not the weapons of a gentleman" (337). Real Dormers and proper representatives for Harsh, it seems, wield the weapons of political power and not the tools of art. Nick has defiantly devoted his powers of reproduction to Miriam and to art and has, in the meantime, neglected to reproduce his family. A supposed adulterer, Nick risks adulteration in his artistic reproductions. He basely represents what is already a representation and thereby shows fidelity to the wrong feminine muse. At the end of the novel, Julia and Nick act as if they will one day be husband and wife. But when Carteret is on his deathbed, Nick leaves with his pencils and brushes but without Carteret's blessing-or his money.

Two art works at the end of The Tragic Muse further demonstrate that some art genres risk vulgar adulteration as they sacrifice the aura of the original, while other arts achieve a fidelity that frees them from reproduction's debasing tendencies. The first of these is the famous image at the end of the novel of the painting Nick renders of Gabriel. While Nick has been coping with various binds as Carteret's heir, Julia's fiancé, and Harsh's representative, Gabriel has remained free of all obligations. His playful self-presentation shows an aesthete's sense of the absurd: "I've grown a tail if you will; I'm the merman wandering free" (115). Neither fish nor flesh, Gabriel blurs distinctions and arrives at the male version of a feminine mythological archetype. While any deviation from the Dormer line constitutes infidelity for Nick, Gabriel can blithely dub himself both an androgyne and a hybrid. Nick pleads with him, "Let me at any rate have some sort of sketch of you as a kind of feather from the angel's wing or a photograph of the ghost-to prove to me in the future that you were a solid sociable fact, that I didn't invent you, didn't launch you as a deadly hoax" (473). Nick compares his proposed portrait to a "photograph of the ghost." Acting as if he could not possibly paint his friend from memory or from imagination, Nick proposes that his own portrait would serve to document Gabriel's existence. If Gabriel is a freeranging "merman," a painting that functions like a photograph might serve to make him "real."

Nick's painting of Gabriel grows more mysterious instead. They begin the work, but Gabriel soon stops coming for his sittings. While Nick waits for him to resume his pose, he finds himself "imagining in the portrait he had begun an odd tendency to fade gradually from the canvas" (475-76). As Nash's image disappears, the fading picture forms a part of a textual conversation with Oscar Wilde's The Picture of Dorian Gray (1891), as Jonathan Freedman has suggested (Professions). But it also inspires an explicit reference to Hawthorne:

He couldn't be caught in the act, but he could have ever a suspicion on glancing at it that the hand of time was rubbing it away little by little- 
for all the world as in some delicate Hawthorne tale-and making the surface indistinct and bare of all resemblance to the model. Of course the moral of the Hawthorne tale would be that this personage would come back in quaint confidence on the day his last projected shadow should have vanished. (TM 476)

The image of Gabriel avoids the eye's scrutiny, gradually fades from the canvas, and foreshadows Gabriel's eventual disappearance from the novel as a whole. By the novel's close, none of the other characters can find him or specify much about him. James's passage seems to refer to Hawthorne's story "The Prophetic Pictures" (1837). A newlywed couple in this early Hawthorne tale sits for a wedding portrait that captures their likenesses, but casts them in a melancholy light. As the first years of their marriage pass, the man and wife come to imitate the crestfallen expressions that their images wear in the portrait. First the couple's image, and then the couple themselves, take on shades of gloom and grief. First Gabriel's image, and then Gabriel himself, similarly fade from The Tragic Muse. In both narratives, the "real" scene of the story lags behind the scene that a picture, embedded within the story, depicts. Nick's "photograph of the ghost" harkens back to Hawthorne's time, when narratives such as The House of the Seven Gables (1852) explored the daguerreotypes and wraiths that occupied antebellum fiction's gothic imagination.

Gabriel fades from both the canvas and the novel but of course reappears quite persistently in the novel's criticism. William Dean Howells confessed when reviewing The Tragic Muse he did not know what James "meant to make" of Gabriel, "whose personality is faintly sketched, and who seems scarcely more than a stalking-horse of clever approaches to the main game." Howells remarks that Gabriel's "taking off is the most effective part," but never explains why his disappearance works so well (421). More recent readers see Gabriel's disappearance as the expulsion of a homosexual or an existential dilemma: Gabriel, "being all unsituated sensation, does not really exist at all" (Ellmann 37). Freedman concludes that "the fading away of the portrait, and the disappearance of Gabriel Nash into 'the ambient air,' may represent not the expulsion of the aesthete from James's work, but rather his incorporation into the ambient air of James's literary consciousness" (Professions 191). Formally banished from the narrative, Gabriel's aestheticism merely transfers from Gabriel to James himself, who engages an aesthete's concerns without having to look like an aesthete before his audience. Eric Haralson sees James's larger comment here on what Gabriel represents and can no longer be made to represent: "As if [his] forced evacuation (or evaporation) were not enough, James emphasizes Nash's resistance to representation-to cultural surveillance, and the regulation that follows in its train-in the fantasy that his image is 'gradually fading from the canvas"” (204). When Nick must either stand for Harsh or stand for art and Miriam's performances obscure her "true" identity, Gabriel alone resists representation.

Gabriel's fading portrait even shows a ready contrast with a different set of representations, which are so abundant that they risk a kind of vulgar overexposure. Miriam comes to possess dozens of publicity photographs as she reaches the 
zenith of success as an actress. At one point she flippantly promises Nick, "I'll bring you a quantity of photographs to-morrow [. . .]. It's so amusing to have them, by the hundred, all for nothing, to give away" (264). Nick wishes to render one special portrait of her in oils, but she offers him easily duplicated, mechanical reproductions. Sara Blair sees the novel "recuperating" Miriam "as a genuine actress whose 'vulgarity'-and whose Jewishness—have been effectively purged" (130). Miriam's "racial otherness" in this reading must be "exorcised of its contagious strain," the "remarkable fecundity" supposedly linked to the Jew (141). But James's novel projects Miriam's fecund capacities onto photography, a new technology of rampant duplication. She becomes abundant but transient, just like the playbills that reproduce her picture. Her many appearances, both on canvas and on film, do not so much indicate Miriam's success as point to her ubiquity. These images each speak to her compromises with audience expectations and to her intermixture of the sincere and the performative, the "pure" and the represented. When Miriam is vulgarly present, and when photographs document her superficial success, Gabriel gracefully fades from Nick's single attempt to capture his image. She becomes a derivative, recycled representation, just when he ceases to appear at all.

Nick's portrait of Gabriel, as a gothic "photograph of the ghost," recalls Jacksonian days before the daguerreotype's invention. Miriam's photos by contrast belong to the 1890 s and the rise of the "Kodak girl," the unskilled dilettante who always had a camera in hand. In explaining that Kodak girls abounded at the turn of the century, Judith Fryer Davidov counts approximately 500 women photographers who published their work in gift books and periodicals within a decade of The Tragic Muse (79, 81). Davidov notes that photography offered a "communal" "means of expression" for women, and concludes that the women's "considerable success in photography had a good deal to do with the fact that their entry into the field coincided with the development of new modes of production of cheap paper and new methods of photoengraving and printing, all of which has its effect on the popular press-which, as it did for women writers, became a vehicle for the publication of their work" (76-77). More people could take pictures, but they could be less discriminating in the pictures they took. James's novel seems to respond by policing photographs for artistic value. Gabriel's escape from "photographic" documentation seems an artful manipulation of the medium. But Miriam's publicity stills become as common as newsprint. The "photograph of the ghost" has fidelity to Hawthorne's day and even alludes to the romancer's art, while Miriam's photographs become part of a starlet's vogue and an indiscriminate "Kodak craze."

In The Tragic Muse, James asks which artists can represent their individual desires, if fidelity in artistic reproductions always constitutes infidelity in terms of national and familial affiliations and if art, with its competing representations and feeble imitations, can ever recover the supposed purity of an original work. Miriam's art seems so compromised that the originality and sincerity of the "real" Miriam disappear. Nick's art almost descends to the same level when his painting of Miriam starts to operate like a camera's "exposure." The male Anglo artist may in the meantime enjoy freedoms that remain out of reach for women and ethnic 
characters. But compared with Gabriel's unbridled existence, Nick's representations mix liberties and obligations. Nick's sister the sculptress is the one left challenging Peter and Nick:

Don't you think art's necessary to the happiness, to the greatness of a people? Don't you think it's manly and honorable? Do you think passion for it's a thing to be ashamed of? Don't you think the artistthe conscientious, the serious one-is as distinguished a member of society as any one else? (404)

Nick and Peter only glance at one another in response, as if dismissing Biddy's idealism. Their careers seem to dictate that men must either serve the nation's needs or serve the muse of art. Society in turn grants artistic license unevenly and favors men over women, Anglo over ethnic artists. But it still watches anxiously to see that even privileged artists "purely" reproduce their forebears' works. James's characters choose carefully among various representations, knowing that photographic duplications may have endangered the few unadulterated originals that remain.

\section{"A photograph of the ghost"}

The themes of reproduction and adulteration that James sets in motion in such places as The Tragic Muse reverberate when he returns to America early in the twentieth century. James records his "impressions" of his drastically altered homeland in The American Scene (1907) and revisits many of his own attitudes toward national affiliation. He finds that some of America's urban immigrant populations have come to abuse the same games of national affiliation that Miriam and Gabriel had begun to play. Without approaching a full reading of The American Scene or A Small Boy and Others, this closing section notes the novelist's attention to "reproduction," in terms of both immigrant populations in America and replication or duplication in art. James, who had so often toured Italy, seems unsettled by the prospect of Italian neighborhoods at home:

The Italians, who, over the whole land, strike us, I am afraid, as, after the Negro and the Chinaman, the human value most easily produced, the Italians meet us, at every turn, only to make us ask what has become of that element of the agreeable address in them which has, from far back, so enhanced for the stranger the interest and pleasure of a visit to their beautiful country. (AS 124-25)

Startlingly large families of immigrants suggest to James that some races have an easier time reproducing than others. He finds himself meeting dark-complected strangers "at every turn," and wondering why individual Italian-Americans so poorly reflect their homeland's charms.

James seems even more daunted in Manhattan's Lower East Side, a quarter of the city that "bristled, at every step, with the signs and sounds, immitigable, unmistakable, of a Jewry that had burst all bounds" (AS 127). "Here was multiplication with a vengeance," he remarks as he notes everything from 
toddlers to septuagenarians. He concludes with uneasy hyperbole that he must be witnessing "the extent of the Hebrew conquest of New York" $(128,129)$. The imperial metaphor provokes searching rhetorical questions: "For what did it really come to but that one had seen with one's eyes the New Jerusalem on earth? What less than that could it all have been, in its far-spreading light and its celestial serenity of multiplication?" (129). The group he had once described as "Rachel's tribe" seems to have founded a new holy city and to be heeding the injunction to multiply. Formerly familiar neighborhoods have become ethnic enclaves, and the newcomers appear to James to resemble swarms of intimidating tribes. Having made his own international search for personal identity, James wonders how to interpret what he sees as remarkable powers of ethnic reproduction: can the New World welcome so many immigrants and allow them to retain vestiges of the Old World as well?

Foreign populations repeatedly provoke such questions for James, and soon he seems to wonder after the fate of the nation's identity and the character of its individual cities. When he visits Ellis Island, James figures the immigration service's ceaseless "drama" as "this visible act of ingurgitation on the part of our body politic and social, and constituting really an appeal to amazement beyond that of any sword-swallowing or fire-swallowing of the circus" (AS 82). The metaphor grotesquely colors one kind of cultural interaction as it shows the nation's body crudely ingesting immigrant populations. America does not meet its recent arrivals on equal terms, it seems, but gulps them down, to spectators' disturbed amazement. Continuous "ingurgitation" eventually compromises the national body. James tells his readers that in recent history "the idea of the country itself underwent something of that profound overhauling through which it appears to suffer the indignity of change" (83). Any alteration of America's founding precepts is apparently a base "indignity" that contrasts with consistent national ideals. James, who after all had spent much of this "overhauling" interval abroad, then begins to speak in terms of "us" and "them":

Is not our instinct in the manner, in general, essentially the safe onethat of keeping the idea simple and strong and continuous, so that it shall be perfectly sound? To touch it overmuch, to pull it about, is to put it in peril of weakening; yet on their free assault upon it, this readjustment of it on their monstrous, presumptuous interest, the aliens, in New York, seemed perpetually to insist. (83)

Established Anglo-Americans, who evidently comprise much of the original audience for James's piece, serve as custodians of America's self-definition. They serve to keep it "simple" and "sound." "Aliens," a group consigned to the thirdperson, abuse that definition's malleability.

The tension between self-definition as family inheritance and self-definition as performance or perception, which James dramatized in The Tragic Muse, has hit home. A childless Anglo-American, James describes his family in A Small Boy and Others as "inveterately yet archaically Irish" (4). He had played with the possibilities of his own identities as an American son of Irish ancestry, as a New 
Yorker living in Europe, and as a citizen of a supposedly philistine or utilitarian country turned artiste. He had felt the freedoms of adopted and hybrid identities and had enjoyed the eclectic atmospheres of international crossroads. In James's fiction, characters such as Miriam Rooth, a kind of biracial chameleon, artfully manipulate identities that fall into interstices between cultures. But when James sees "a Jewry that had burst all bounds," he seems to revert to speaking in terms of "us" and "them." Nimbly mixing tribes in his art, he turns tribal in his memoir when he notes sweeping demographic changes. The games of national affiliation and performative identity turn serious when immigrants overwhelm the "natives" and when middle-class neighborhoods become ethnic ghettos.

Many readers of The American Scene see James adapting foreign influences and working outside accepted definitions of national affiliation in favor of free and flexible identities (Blair, Peyser, Posnock). James indeed delights in many of the country's pastoral scenes and resists imposing himself upon them by making his mode of narration inventively elusive and contingent. But this critical approach emphasizes James's shifting mode of narration and playful, boundless curiosity, while discounting some of his more visceral reactions to imposing foreign populations. A more fruitful reading sees James sharing both a need to preserve a national identity and a desire to make American citizenship a more elastic concept. In Thomas Peyser's phrase,

The elusiveness of James's attachment to contemporary notions of a specifically Anglo-Saxon destiny derives from his finding himself on the cusp between hard-and-fast definitions of the English-speaking races and a more fluid idea of a whiteness purified to the state of colorlessness, equipped successively to absorb all 'aliens,"” regardless of their national origins. (161)

Indeed, "whiteness" is increasingly fluid for James, who also feels the loss of familiar demographic distinctions. James's memoir clearly senses that foreign influences can enrich an increasingly eclectic America. But at the same time, performed identities and "alien" populations can further dilute whatever remained of a "pure" national heritage. When New York becomes ethnically mixed, an increasingly displaced James senses that immigrant groups have abused the definitions within which James had performed his American identity.

If Miriam's photographic reproductions had obscured her "true" identity and suggested infidelity to her tribe, a different photographic image out of James family history serves to secure the novelist's own identity and indicate his fidelity. Several chapters into A Small Boy and Others, James writes,

I cherish, to the extent of here reproducing, an old daguerreotype all the circumstances of the taking of which I intensely recall-though as I was lately turned twelve when I figured for it the feat of memory is perhaps not remarkable. It documents for me in so welcome and so definite a manner my father's cultivation of my company. (69) 
James is in fact "reproducing" the 1855 Brady daguerreotype of himself and his father, making the now-famous image the frontispiece of the 1913 edition of $A$ Small Boy and Others. James of course had included Alvin Langdon Coburn's photographs as the frontispieces of the New York editions of his novels. But, as many readers have suggested, these photographs avoid distinct images in favor of evocative but unpopulated scenes, likely settings for carefully selected moments in James's narratives. ${ }^{8}$ Brady's image of the elder and younger Henry James, then, strikingly contrasts with the photographs of the New York Edition. It directly records a moment of James family history, depicts two of the book's main characters, and "reproduces" a visual episode in James's memoir. The moment remembered in the photograph highlights the elder James's "cultivation" of the novelist's company. Father and son had surreptitiously visited Brady's Manhattan studio when James was twelve, hoping "to keep the affair secret till the charming consequence should break, at home, upon my mother" (SB 86). The surprise portrait for Mary James pointedly excludes Henry's older brother William, who usually received a great deal of their parents' attention. The image that Henry James Jr. "cherish[es], to the extent of reproducing," then, recreates his family's intimacy while it excludes his sibling from the picture frame.

If the image itself is limited and exclusive, the chain of associations that it inspires is rich and extensive. Thirty pages of the 1913 edition of the memoir revolve loosely around Brady's image. James narrates his memories of 1855 Manhattan, where the father and son had made their way through a bustling August afternoon to Brady's studio. Farmers' markets strewn with bundles and boxes of summer fruit come back to the reminiscing James as "some vast succulent cornucopia" ( $S B$ 70). The mental images prompt him to ask, "What did the stacked boxes and baskets of our youth represent but the boundless fruitage of that more bucolic age of the American world, and what was after all of so strong an assault as the rankness of such a harvest?" An Arcadian and "bucolic" atmosphere seems overripe with natural bounty. Brady's image imaginatively transports James to his boyhood in a country that had yet to experience the urbanization and immigration that, to James's perception, would so alter the country's character.

James even recalls that the jacket he had worn on the "day of the daguerreotype" ( $S B$ 92), adorned with shiny buttons, had once captured the attention of another literary forebear. The English novelist William Thackeray had been visiting Henry James Sr. when he had noticed an adolescent Henry hovering nearby and wearing the same jacket he had worn for the daguerreotype. As students of literary influences on the young Henry James Jr. have long noted, an avuncular Thackeray had doted on Henry and had said that in Britain the boy would promptly have been dubbed "Buttons." James explains that with this memory, "it had been revealed to me thus in a flash that we were somehow queer, and though never exactly crushed by it I became aware that I at least felt so as I stood with my head in Mr Brady's vise" (SB 88). Posing for Brady's camera and wearing the jacket that Thackeray had admired, James sensed his own budding distinctiveness, pinned down, as it were, for the camera's scrutiny. Later chapters of the memoir claim Thackeray as an important literary influence, making the 
image of the young James as "Buttons" and the Brady daguerreotype instrumental to their relationship. "Beautiful most decidedly the lost art of the daguerreotype," remarks James, who says he can "remember the 'exposure' as on this occasion interminably long, yet with the result of a facial anguish far less harshly reproduced than my suffered snapshots of a later age" (SB 88). Miriam's variety of newspaper snapshots seem to have supplanted the superior daguerreotype, a "lost art" which had once been kinder to James's physiognomy. He reproduces the photograph in A Small Boy and Others as if to perpetuate his memories further, and as if to include his readers in his rush of nostalgia.

Miriam's photographs replicate what is already an enacted performance, taking the viewer ever further from the "truth" about her character. James's own photograph seems by contrast to pose as a conduit to a young James who felt his family's "cultivation of [his] company," who gained the attention of an established novelist, and who felt little need as of yet to enact any role, as an American or as a literary artist. Miriam's images seem to represent alterable and liberating identities, but also to suggest nationalities that have become too "adulterated," from excesses of performance and reproduction. James's family image is a return to origins, a means of imaginatively recovering a time before the need for such performances and before the country had experienced its first supposed adulteration. It even becomes a point of origin for the aging novelist's sense of his own past. Miriam's snapshots only risk a voguish popularity, while James's photograph becomes an enduring portrait of the artist as a young man.

In publishing A Small Boy and Others, James even seems to be following Nick Dormer's lead in choosing a mode of artistic reproduction. Long before the time of the novel's action, Nick's father died. Nick chose the art of painting over what might be seen as a more practical, responsible career. He had not reproduced his family in a new line of Dormers for Harsh, but had instead reproduced models, some of them more foreign than British, on his canvases. Not so long-eight years-before the publication of the same novel, James's own father died. James had not reproduced his family in a new generation, but had of course created fictional lives in his many narratives. Protagonist and novelist alike, then, use their art to make amends: Nick's painting of Gabriel fades, ghost-like, from the canvas, even as it recalls Hawthorne's gothic tales from half a century earlier. James's family portrait lovingly brings back the spirit of James's father from the same antebellum era. They recreate artful images that recall their fathers' bygone days of shadowy daguerreotypes. In such hallowed images, each of these artists can highlight his family fidelity, avoid the excessive and vulgar representations of a latter day, and faithfully reproduce a "photograph of the ghost."

NOTES

I would like to thank Robert Milder, Wayne Fields, Rafia Zafar, Iver Bernstein and Ronald Leax for their criticism of an earlier draft of this essay, Vivian R. Pollak for her indispensable guidance and advice, and Sheila Decker for her mot juste.

${ }^{1}$ Bogardus and Shloss, in the 1980s, and Schwarzschild, Grossman, Williams, Rawlings, Miller, and Nadel, in more recent years, have contributed to critical histories of James and photography and have concentrated most often on "The Real Thing," The Golden Bowl, and the James-Coburn relationship. The photographs in The Tragic Muse seldom appear in these histories.

${ }^{2}$ Ben-Joseph remarks that James "found it appropriate to make his Tragic Muse something of a Shylock" (114), and that overall, "the substantive fact of [James's] antisemitism is clear" (171). 
Freedman presents a more moderate view. Freedman sees that "James's labile response to the Jew enacts a kind of working through by means of a response to an abjected creature" ("Discourses" 82) and concludes that James was "saner," "more open and more generous on every level" than many of his contemporaries, though "Henry was undeniably less generous than brother William" (80).

${ }^{3}$ Rowe, Wilson, Haralson, and Storm have analyzed potential homoeroticism among the often classist, anti-Semitic, and sexist relationships in The Tragic Muse.

4"Fidelity" had denoted "conjugal faithfulness" or "honesty and truthfulness" in individuals since the seventeenth century, and came in the eighteenth century to mean a translation's truth to the language of the original text. The $O E D$ records the first usages of the term to mean "the degree to which a sound or picture reproduced or transmitted by any device resembles the original" in the 1870 s. James, then, is one of the originators of this relatively new coinage in 1865 .

${ }^{5}$ Edel originally interpreted Herbert Pratt, a "man of some means" and a "wanderer upon the face of the earth," whom James met in Europe in 1881 (265), as the real-life prototype for Gabriel. Freedman argues that Gabriel is James's understanding of the liberated and sexually ambiguous artist of the Wildean school of aesthetes and decadents (Professions), and Ellman discusses Gabriel as well as other Jamesian heroes with regard to these same dynamics.

6"[W] have no direct exhibition of hers [Miriam's consciousness] whatever, that we get it all inferentially and inductively, seeing it only through a more or less bewildered interpretation of it by others" (TM 8). James aims, then, for "an absolutely objective Miriam," only representing this character as she represents herself to her observers.

${ }^{7}$ Rawlings cautions readers not to group all of James's invocations of photography transhistorically. Readers would be mistaken, Rawlings explains, to group the ubiquitous Kodak snapshots with photographic artistry such as that of Alfred Stieglitz. This historical interval, which Rawlings calls the "Kodak moment," saw the sudden emergence of cheaply reproduced photographic images that briefly made the whole enterprise of photography seem transient and shoddy.

${ }^{8}$ See Bogardus, Edel, Schwarzschild, Rawlings, and Grossman for critical readings of these photographs as accompaniments to James's prose. See as well Nadel and Miller for readings of the role of the Coburn photographs in the construction of the New York editions.

\section{WORKS BY HENRY JAMES}

AS-The American Scene. New York: Harper, 1907.

CM-The Critical Muse: Selected Literary Criticism. Ed. Roger Gard. New York: Penguin, 1987.

RH-Roderick Hudson. Ed. Geoffrey Moore. New York: Penguin, 1986.

$S B-A$ Small Boy and Others. New York: Scribner's, 1913.

TM-The Tragic Muse. Ed. Philip Horne. New York: Penguin, 1995.

\section{OTHER WORKS CITED}

Ben-Joseph, Eli. Aesthetic Persuasion: Henry James, the Jews, and Race. New York: UP of America, 1996.

Blair, Sara. Henry James and the Writing of Race and Nation. New York: Cambridge UP, 1996.

Bogardus, Ralph. Pictures and Texts: Henry James, A. L. Coburn, and New Ways of Seeing in Visual Culture. Ann Arbor: UMI, 1984.

Davidov, Judith Fryer. Women's Camera Work: Self/Body/Other in American Visual Culture. Durham: Duke UP, 1998.

Edel, Leon. Henry James: A Life. New York: Harper, 1985.

Ellmann, Richard. "James among the Aesthetes." Henry James and Homoerotic Desire. Ed. John R. Bradley. New York: St. Martin's, 1999. 25-44.

Freedman, Jonathan. "Henry James and the Discourses of Antisemitism." Between "Race" and Culture: Representations of "The Jew" in English and American Literature. Ed. Bryan Cheyette. Stanford: Stanford UP, 1996. 62-83.

- Professions of Taste: Henry James, British Aestheticism, and Commodity Culture. Stanford: Stanford UP, 1990.

Grossman, Julie. “'It's the Real Thing': Henry James, Photography, and The Golden Bowl.” Henry James Review 15 (1994): 309-28.

Haralson, Eric. “The Elusive Queerness of Henry James's 'Queer Comrade': Reading Gabriel Nash in The Tragic Muse." Victorian Sexual Dissidence. Ed. Richard Dellamora. Chicago: U of Chicago P, 1999. 191-210.

Hawthorne, Nathaniel. "The Prophetic Pictures." Tales and Sketches: Including Twice-Told Tales, Mosses from an Old Manse, and The Snow Image. New York: Library of America, 1996. 459-69.

Howells, William Dean. Review of The Tragic Muse. Atlantic Monthly 66 (1890): 419-22. 
Landau, John. "A Thing Divided": Representation in the Late Novels of Henry James. Madison: Farleigh Dickinson UP, 1996.

Miller, J. Hillis. “The 'Grafted' Image: James on Illustration.” Henry James's New York Edition: The Construction of Authorship. Ed. David McWhirter. Stanford: Stanford UP, 1995. 138-42.

Nadel, Ira B. "Visual Culture: The Photo Frontispieces of the New York Edition." Henry James's New York Edition: The Construction of Authorship. Ed. David McWhirter. Stanford: Stanford UP, 1995. 109-24.

Peyser, Thomas. Utopia and Cosmopolis: Globalization in the Era of American Literary Realism. Durham: Duke UP, 1998.

Posnock, Ross. The Trial of Curiosity: Henry James, William James, and the Challenge of Modernity. New York: Oxford UP, 1991.

Rawlings, Peter. “A Kodak Refraction of Henry James's 'The Real Thing." Journal of American Studies 32 (1998): 447-63.

Rowe, John Carlos. The Other Henry James. Durham: Duke UP, 1998.

Schwarzschild, Edward L. "Revising Vulnerability: Henry James's Confrontation with Photography." Texas Studies in Language and Literature 38.1 (1996): 51-78.

Shloss, Carol. In Visible Light: Photography and the American Writer, 1840-1940. New York: Oxford UP, 1987.

Storm, William. "Henry James's Conscious Muse: Design for a 'Theatrical Case' in The Tragic Muse." Henry James Review 21 (2000): 133-50.

Williams, Susan S. Confounding Images: Photography and Portraiture in Antebellum American Fiction. Philadelphia: U of Pennsylvania P, 1997.

Wilson, Michael L. J. "To Feel is Such a Career': Gender and Vocation in The Tragic Muse." Questioning the Master: Gender and Sexuality in Henry James's Writings. Ed. Peggy McCormack. Newark: U of Delaware P, 2000. 104-32. 